\title{
Ammonia Nitrogen Removal from Domestic Wastewater via Nitrification Process Using Aerated Rock Filter
}

\author{
Rafidah Hamdan ${ }^{1, a^{*}}$, Izzati Izwanni Ibrahim ${ }^{2, \mathrm{~b}}$ and Siti Zahirah Haron ${ }^{3, \mathrm{c}}$ \\ ${ }^{1,3}$ Department of Water and Environmental Engineering, Faculty of Civil and Environmental \\ Engineering, University Tun Hussein Onn Malaysia, 86400 Parit Raja, Batu Pahat, Johor \\ ${ }^{2}$ Department of Civil Engineering Technology, Faculty of Engineering Technology, University Tun \\ Hussein Onn Malaysia, 86400 Parit Raja, Batu Pahat, Johor \\ arafidahh@uthm.edu.my, bizzatiibraka@gmail.com, ‘eahirah@gmail.com
}

Keywords: Ammonia nitrogen removal, aerated rock filter, domestic wastewater, nitrification process.

\begin{abstract}
Domestic wastewater has a complex composition and poses harmful effects to the environment if it is not properly treated prior as it can be safely discharged to the surface waterbody. Pertaining to this matter, nitrogen in particular has a great impact towards the environment as it will cause eutrophication to the water body and it is a global concern. Nitrogen removal from wastewater through conventional wastewater treatment requires high additional chemical cost and high in sludge production. In line with this situation, rock filters (RF) emerged as one of the attractive natural wastewater treatment method to treat wastewater high in nutrient as the filter system is simple and easy to maintain. In addition, the system can be classified a low-cost technology due to the used of locally available and waste material for filter media. However, the design of the ARF system to enhance the removal of nitrogen due to nitrification study under warm climate is still lacking. Thus, the laboratory-scale ARF system has been designed in this present study to study the effectiveness of the system in removing AN from domestic wastewater. The laboratory-scale ARF system has been operated for approximately two months at hydraulic loading rate and aeration rate of $0.6 \mathrm{~m}^{3} / \mathrm{m}^{3} . \mathrm{d}$ and $0.3 \mathrm{~L} / \mathrm{min}$, respectively using wastewater samples from Taman Bukit Perdana WWTP. Grab samples of the filter influent and effluent have been collected and analyzed twice a week for Total Kjeldahl Nitrogen (TKN, AN, nitrates , $\mathrm{pH}$, temperature, DO and alkalinity to monitor the effectiveness of the ARF filter in removing nitrogen. Results from the laboratory experiments show that $\mathrm{AN}$ in wastewater was oxidized to nitrate and efficiently removed as the removal of ammonia nitrogen was ranged from $66.05 \%$ to $91.30 \%$ and the removal percentage of TKN was ranged from $63.23 \%$ to $87.68 \%$. The temperature, $\mathrm{pH}$ values, DO and alkalinity were range from $25^{\circ} \mathrm{C}$ to $27.5^{\circ} \mathrm{C}, 6.34$ to $8.04,6.64 \mathrm{mg} / \mathrm{L}$ to $7.75 \mathrm{mg} / \mathrm{L}$, and 15 to 110 as $\mathrm{mg} / \mathrm{L} \mathrm{CaCO}_{3}$, respectively. From this experimental results, it can be concluded that the ARF system has high potential in removing $\mathrm{AN}$ and TKN. In addition, the system also able to produce a good final effluent quality which is comply with the effluent requirement for nutrient removal in wastewater under the Environmental Quality Act (Sewage) Regulations, 2009 that is safe to be released to the water body.
\end{abstract}

\section{Introduction}

Eutrophication is the process by which water bodies are made more eutrophic through an increasing of nutrient supply. Nitrogen $(\mathrm{N})$ pollution is one of the major threats to the coastal oceans in the world caused by human-accelerated global change as concluded in 'whitepaper panel' of the Ecological Society of America [Vitousek et al. 1997] and the Coastal Marine Team of the National Climate Change Assessment [Boesch et al. 2000; Scavia et al. 2002] cited in [1]. Moreover, human activities also contribute excessive amounts of plant nutrients such as nitrogen and phosphorus as reported by [2] that both nitrogen and phosphorus compounds among the 
principal constituents of concern in wastewater due to their role in eutrophication, effect on the oxygen content of receiving waters, and their toxicity to aquatic life. According to Pan et al., [3], the main pathway of nitrogen removal from domestic wastewater in aerated rock filter (ARF) system is similar to the constructed wetland (CW) system, that is biological conversion through nitrification and denitrification processes. CW system in Poland showed that the majority of nitrogen has been removed through nitrification and denitrification [4]. Nitrification is the biological oxidation of ammonia (which exists mostly as $\mathrm{NH}_{4}{ }^{+} \mathrm{N}$ in typical wastewater) to nitrite $\left(\mathrm{NO}_{2}{ }^{-} \mathrm{N}\right)$ and then oxidation of nitrite to nitrate $\left(\mathrm{NO}_{3}{ }^{-} \mathrm{N}\right)$. Nitrification take place almost systematically in warm climate regions unless there is some environmental problem in the aeration tank, such as low of dissolved oxygen level, low $\mathrm{pH}$ and the presence of toxic or inhibiting substances. In nitrification process, ammonia nitrogen is converted to nitrate utilizing two purely aerobic autotrophs; they are Nitrosomonas and Nitrobacter bacteria. Both bacteria are instrumental in completing nitrification in aerobic condition.

\section{Materials and Methods}

The laboratory-scale ARF system has been set up in the Environmental Laboratory FKAAS, UTHM for approximately two months and five weeks of sampling. The wastewater samples for this experiment has been collected at Indah Water Konsortium Wastewater Treatment Plant (WWTP) located at Bukit Perdana, Batu Pahat, Johor. During the monitoring period, grab samples of the influent and effluent of the ARF were collected and analysed biweekly, following Standard Methods for Water and Wastewater Examinations [5], for BOD (method no. 5210-B), COD (5220C), ammonia (4500- $\left.\mathrm{NH}_{3} \mathrm{D}\right)$, TKN (4500-N $\left.\mathrm{N}_{\text {org }} \mathrm{C}\right)$ TSS (2540-D), and alkalinity (2320 B). Dissolved oxygen, $\mathrm{pH}$, and temperature were measured in situ using YSI probe (model Hach HQ440d), and nitrate was analyzed weekly using DIONEX ion analyser (model ICS-2000, USA).

The laboratory-scale ARF consists of clear perspex cylindrical with internal diameter $0.144 \mathrm{~m}$ and height $0.275 \mathrm{~m}$ by using steel slag as a filter media. The hydraulic loading rate (HLR) and aeration rate of the ARF system were maintained at $0.6 \mathrm{~m}^{3} / \mathrm{m}^{3} . \mathrm{d}$ and $0.3 \mathrm{~L} / \mathrm{min}$, respectively. The wastewater from storage tank has been flowed by gravity method at the base of the filter and aerated by using a compressor. The layout of the ARF set up in this experiment is given in Fig. 1

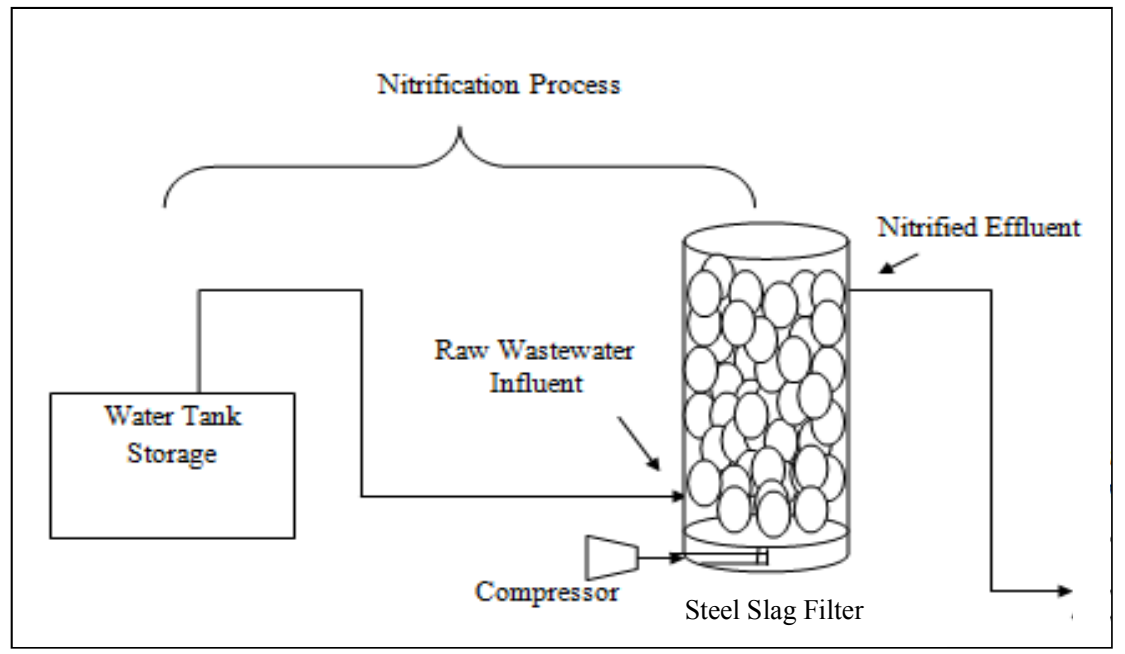

Fig. 1: The lab-scale ARF system experiment Layout

\section{Result and Discussion}

The average of removal efficiencies and final effluent concentrations in the ARF system is shown in Table 1. Results from this experiments show that the system has a promising capability in producing a very good quality of final effluent as the concentration of AN in effluent was $6.20 \pm$ 
$2.38 \mathrm{mg} / \mathrm{L} \mathrm{NH} \mathrm{NH}_{3} \mathrm{~N}$. Aerated condition in the ARF system also provide a favorable condition of nitrification to occur as nitrate concentration in effluent is average at $35.50 \pm 2.51 \mathrm{mg} / \mathrm{L} \mathrm{NO}_{3}{ }^{-}$.

Table 1: Final effluent of ARF

\begin{tabular}{|c|c|c|}
\hline Parameter & Removal efficiency (\%) & Final effluent concentration \pm s.d \\
\hline TKN & $63.23-87.68$ & $6.82 \pm 2.25$ \\
\hline AN & $66.00-91.30$ & $6.20 \pm 2.38$ \\
\hline Nitrate & - & $35.50 \pm 2.51$ \\
\hline DO & - & $7.35 \pm 0.37$ \\
\hline pH & - & $7.45 \pm 0.47$ \\
\hline Temperature & - & $26.30 \pm 0.75$ \\
\hline Alkalinity & - & $74.00 \pm 27.16$ \\
\hline
\end{tabular}

*All units are $\mathrm{mg} / \mathrm{L}$ except $\mathrm{pH}$ and turbidity (NTU)

\section{Total Kjeldahl Nitrogen (TKN) Removal}

TKN removal was found to be slightly higher after treated in ARF system. The average influent of TKN concentration was $31.70 \pm 2.87 \mathrm{mg} / \mathrm{L}$ whilst in the effluent it was $6.82 \pm 2.25 \mathrm{mg} / \mathrm{L}$. The average of ARF system removal efficiency was $78 \%$ as illustrated in Fig. 2. It shows that nitrification process was occurred and the result was supported by Gerardi [6] that TKN will affect the dissolved oxygen (DO) during the degradation. In addition, the most important factors impact on the removal of TKN is the mass loading rate, temperature, and oxygen transfer [7].
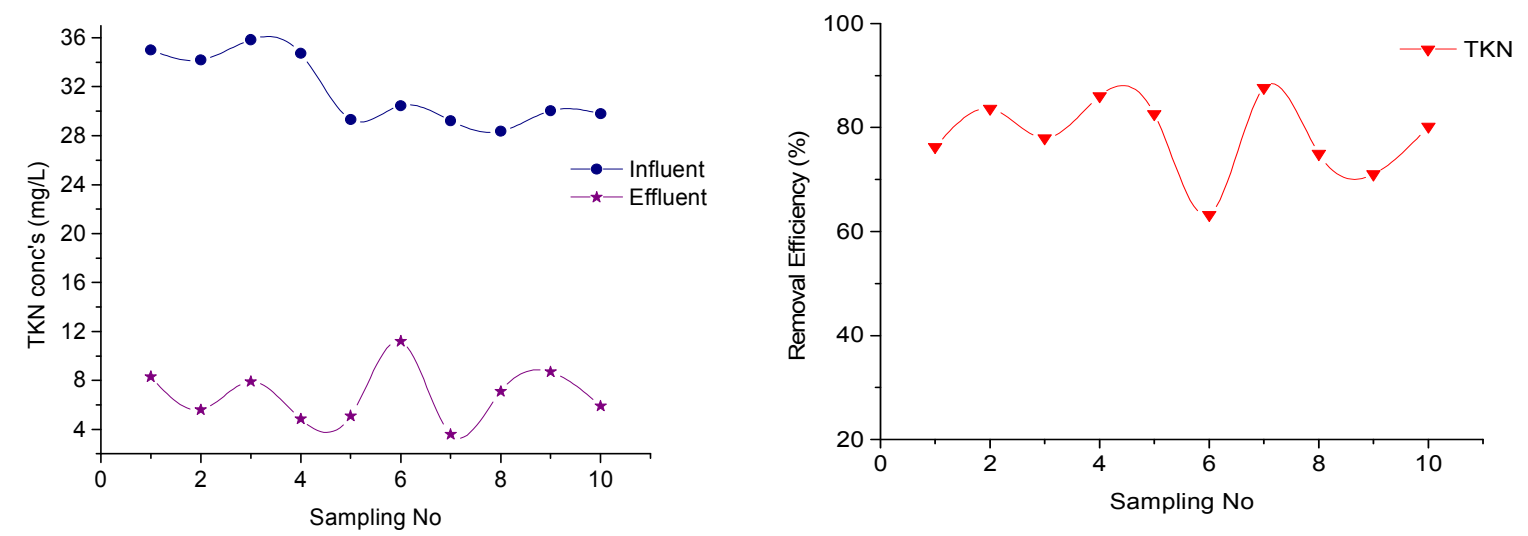

Fig. 2: TKN Concentration and Removal Efficiency

\section{Ammonia Nitrogen (AN) Removal}

AN from wastewater had an average concentration of $29.70 \pm 2.78 \mathrm{mg} / \mathrm{L}$ in influent and has been reduced to an average of $6.20 \pm 2.38 \mathrm{mg} / \mathrm{L}$ in ARF. Meanwhile, AN removal efficiencies in the ARF was successfully treated which produced an averaged of $79 \%$ as shown in Fig. 3 . This is because the bacteria known as Nitrosomonas convert ammonia to nitrite and bacteria called Nitrobacter will complete this process by conversion of nitrite to nitrate [8]. Besides that, nitrification process is also successful because of $\mathrm{pH}$, temperature, $\mathrm{DO}$, and alkalinity readings stood at optimum impact on the process of nitrification. 

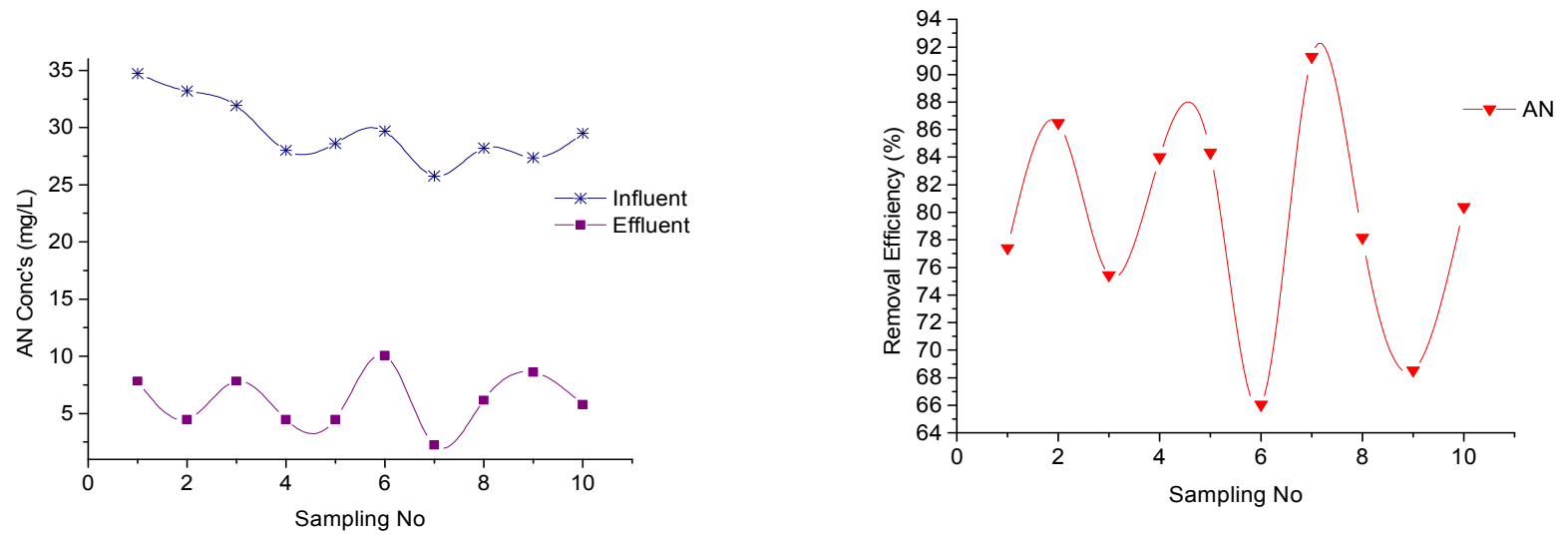

Fig. 3: AN Concentration and Removal Efficiency

Dissolved oxygen (DO) was found to be higher in the ARF effluent with an average $7.35 \pm 0.37$ $\mathrm{mg} / \mathrm{L}$ compared to the influent average was $2.75 \pm 1.63 \mathrm{mg} / \mathrm{L}$ as pointed in Fig. 4 . It indicated that nitrification process only occurs under aerobic conditions at dissolved oxygen (DO) levels of 1.0 $\mathrm{mg} / \mathrm{L}$ or more whilst when DO concentration less than $0.5 \mathrm{mg} / \mathrm{L}$, the growth rate is minimal as indicated in [6].

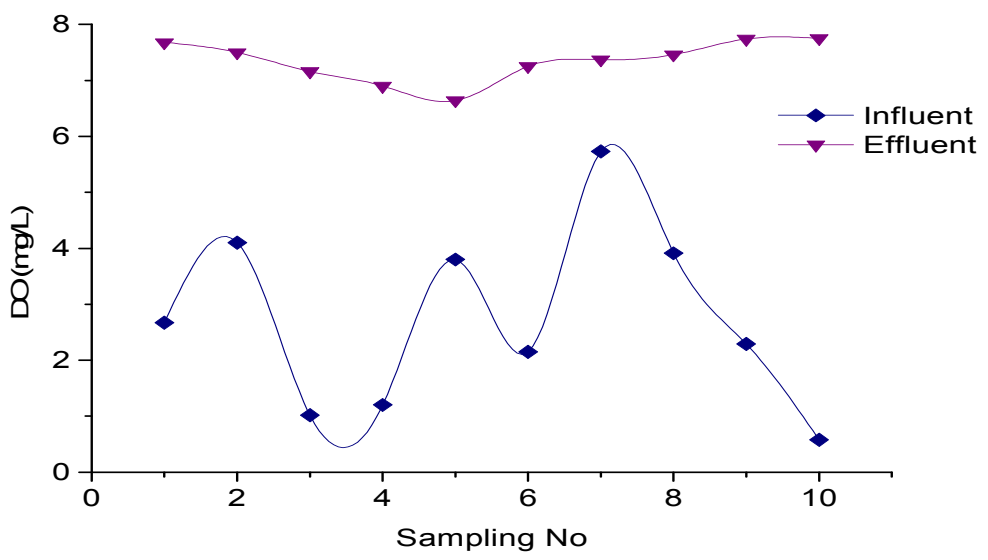

Fig. 4: DO Profile

\section{Temperature}

Wastewater temperature is usually between $10^{\circ} \mathrm{C}$ to $20^{\circ} \mathrm{C}$ while the optimum temperature for nitrification process is $30^{\circ} \mathrm{C}$ and the temperature will cease when the temperature achieve of $5^{\circ} \mathrm{C}$. At temperature of $40^{\circ} \mathrm{C}$ and above, the rate of nitrification dropped to almost zero. Therefore, for this experiment the temperature obtained for the occurrence of nitrification process is approaching the optimum temperature with an averaged range $26.30^{\circ} \mathrm{C} \pm 0.75^{\circ} \mathrm{C}$ as illustrated in Fig. 5 . 


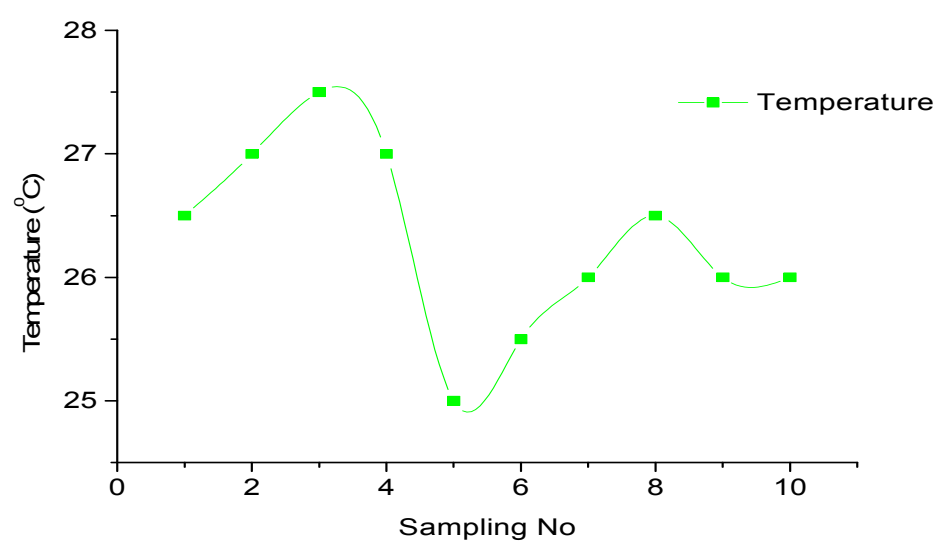

Fig. 5: Temperature Profile

\section{Conclusion}

In conclusion, the ARF system has been outperformed during the laboratory experiment as the system has efficiently removed AN and TKN from domestic wastewater. From the results, the highest percentage removal of ammonia nitrogen was $91.30 \%$ at sample 7 . Nitrification process was observed to occur within the ARF system due to the aerated condition where ammonia in the forms of $\mathrm{NH}_{3}$ and $\mathrm{NH}_{4}^{+}$in wastewater oxidized into nitrate through biological activities of nitrifiers. In addition, the ARF system able to produce a good final effluent quality which is comply with the effluent requirement Environmental Quality Act (Sewage) Regulations, 2009.

\section{References}

[1] Howarth, R.W. \& Marino, R., (2006). Nitrogen as the limiting nutrient for eutrophication in coastal marine ecosystems: Evolving views over three decades. Limnology and Oceanography, 51(1, part 2), pp.364-376.

[2] Lin, L. et al., (2009). Removal of Ammonia Nitrogen in Wastewater by Microwave Radiation. Journal of Hazardous Material (161), pp.1063-1068.

[3] Pan, J. et al., (2012). Full-Scale Experiment on Domestic Wastewater Treatment by Combining Artificial Aeration Vertical-and Horizontal-Flow Constructed Wetlands System. Water, Air, \& Soil Pollution, 223(9), pp.5673-5683.

[4] Ostrowska, K. et al., (2013a). Nitrogen Removal in Vertical-Flow Filters Filled with Lightweight Aggregate Made of Fly Ashes and Gravel. , Journal of Environmental Engineering, pp.1266-1272.

[5] Standard Methods for the Examination of Water and Wastewater, 21st ed. American Public Health Association, Washington, DC, 2005.

[6] Gerardi, M. H. (2006). Wastewater Microbiology: Wastewater Bacteria, United States of America: John Wiley and Son, Inc., New York.

[7] Water Environment Federation (2011). Water Resources and Environment Engineering, WEF Pres.

[8] Valero, M. (2008). Nitrogen Transformation Pathways and Removal Mechanisms in Domestic Wastewater Treatment by Maturation Ponds. Ph.D. Thesis. The University of Leeds, School of Civil Engineering. 